\title{
New species of Eupalaestrus from Argentina (Araneae, Theraphosidae, Theraphosinae)
}

\author{
Nelson Ferretti \& Jorge Barneche
}

Centro de Estudios Parasitológicos y de Vectores - CEPAVE (CCT- CONICET, La Plata) (UNLP), La Plata, Argentina. (nferretti@conicet.gov.ar; grammostola15@hotmail.com)

\begin{abstract}
A new species of Eupalaestrus Pocock, 1901 from northern Argentina is described and illustrated. Males and females of Eupalaestrus larae sp. nov. differ from those all other species of the genus by the color with distinct two parallel longitudinal stripes on the femora, patellae, tibiae and one longitudinal stripe reaching half of metatarsi; the presence of a thickened femur and tibia IV; a straight embolus of the male palpal bulb and retrolateral keel pronounced. Specimens were captured in Chaco province, inhabiting unflooded flat grasslands open areas inside forest in transitional Chaco eco-region.
\end{abstract}

KEYWORDS. Taxonomy, Natural History, Neotropical, Chaco.

RESUMEN. Nueva especie de Eupalaestrus de Argentina (Araneae, Theraphosidae, Theraphosinae). Una nueva especie de Eupalaestrus Pocock, 1901 del norte de Argentina es descripta e ilustrada. Machos y hembras de Eupalaestrus larae sp. nov. difieren del resto de las especies de género por el color con dos líneas paralelas longitudinales distintivas en fémures, patelas y tibias y una línea longitudinal alcanzando la mitad del metatarso; la presencia del fémur y tibia IV ensanchados; un émbolo recto en el bulbo palpal del macho y una quilla retrolateral pronunciada. Los especímenes se capturaron en la provincia de Chaco, habitando un pastizal abierto no inundable dentro de bosques en la eco-región de Chaco transicional.

PALABRAS-CLAVE. Taxonomía, Historia Natural, Neotropical, Chaco.

Theraphosidae is a family of spiders with 932 described species (Platnick, 2012), comprising more than one third of the mygalomorph species (CODDINGTON \& LeVI, 1991). It is distributed throughout all tropical and many subtropical areas in all continents and includes many of the largest spider species. Very little is known on the biology of the Theraphosidae, and its taxonomy is in a chaotic state (RAVEN, 1990).

The genus Eupalaestrus Pocock, 1901 comprises four species recorded in Guyana, Brazil, Paraguay, Uruguay and Argentina (Platnick, 2012). The type species, Eupalaestrus pugilator Pocock, 1901 was described by original designation and monotypy. Eurypelma campestratum Simon, 1891 is based on specimens from Paraguay. Simon (1903) transferred it to Eupalaestrus campestratus (Simon, 1891). Lasiodora weijenberghi Thorell, 1894 was described by based on males from Córdoba province, Argentina. MeLLo-Leitão (1941) synonymized it with Weyenberghia weijenberghi and later Schiapelli \& Gerschman de Pikelin (1979) transferred it to Pterinopelma weijenberghi. Finally, Pérez-Miles (1992) transferred Pterinopelma weijenberghi to Eupalaestrus weijenberghi (Thorell, 1894). Eupalaestrus spinosissimus Mello-Leitão, 1923 was originally described based on specimens from Rio de Janeiro, Brazil. Later, Bücherl (1947) described E. tarsicrassus with a female from São José dos Campos, São Paulo, Brazil. Finally E. tarsicrassus was considered a junior synonym of $E$. spinosissimus, but unfortunately the male still unknown (BERTANI, 2001). The last species described in this genus was E. guyanus (Simon, 1892) of Guyana resulting from the transfer of Eurypelma guyanum Simon, 1892 to Eupalaestrus (GABriel, 2009).
In a recent survey carried out in Presidencia Roque Sáenz Peña, Chaco province, Argentina, a new species of Eupalaestrus was discovered and is herein described.

\section{MATERIAL AND METHODS}

The following abbreviations are utilized: A, male palpal bulb apical keel; ALE, anterior lateral eyes; AME, anterior median eyes; $\mathrm{d}$, dorsal; $\mathrm{OQ}$, ocular quadrangle (including lateral eyes); p, prolateral; PI, male palpal bulb prolateral inferior keel; PLE, posterior lateral eyes; PME, posterior median eyes; PS, male palpal bulb prolateral superior keel; r, retrolateral; R, male palpal bulb retrolateral keel; SA, male palpal bulb subapical keel; v, ventral. The material studied are deposited in the arachnological collection of the Museo de La Plata (MLP, Luis Pereira), Buenos Aires, Argentina. Spine notation follows Petrunkevitch (1925). Palpal bulb structure classification follows BERTANI (2000). Urticating hairs classification follows COOKE et al. (1972). We made measurements using a stereomicroscope equipped with a calibrated ocular micrometer scale and a digital caliper with an error of 0.01 millimeters rounded up to one significant decimal where appropriate. Images of the specimens were obtained under a stereomicroscope with a mounted digital camera. All measurements are in millimeters.

\section{Eupalaestrus larae sp. nov.} (Figs 1-7, 9)

Type material. Holotype $\delta$, Argentina, Chaco, Presidencia Roque Sáenz Peña (2651'79’'S 60²6’15”W), 
X.2006, J. Barneche col. (MLP 19030). Paratypes: with same data as holotype, $\widehat{o}$ (MLP 19031), ( (MLP 19032).

Etymology. This species is named in honor of $\mathrm{J}$. Barneche's daughter, Lara.

Diagnosis. Males and females of Eupalaestrus larae sp. nov. differ from those all other species of the genus by the color with distinct two parallel longitudinal stripes on the femora, patellae, tibiae and one longitudinal stripe reaching half of metatarsi (Figs 1, 5). Eupalaestrus larae sp. nov. differs from $E$. weijenberghi by the thickened femur III; from $E$. spinosissimus by the absence of stiff setae on tibia and metatarsus IV and from E. guyanus by the less circular main body of the male palpal bulb (illustrated by Gabriel, 2009). Eupalaestrus larae sp. nov. resembles E. campestratus by the color pattern and the thickened tibia IV but differs from this species by the presence of a thickened femur and tibia IV (Fig. 7) and by the straighter embolus of the male palpal bulb and retrolateral keel pronounced (Figs 3, 4) (illustrated by BERTANI, 2001).

Male holotype (MLP 19030) (Fig. 1). Total length, not including chelicerae and spinnerets, 45.72.
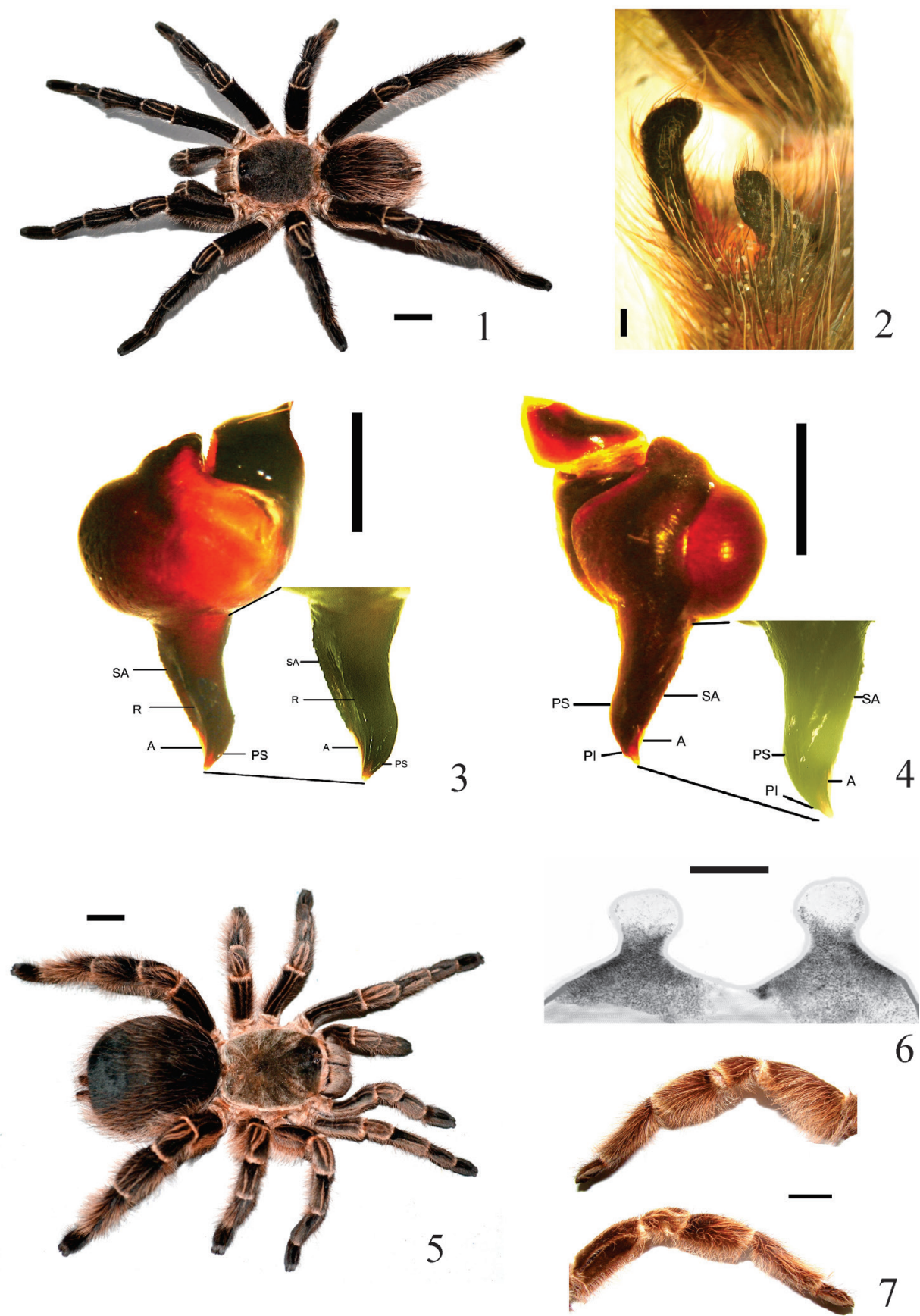

Figs 1-7. Eupalaestrus larae sp. nov.: 1, holotype male, habitus; 2, right male spur; male palpal bulb: 3, retrolateral; 4, prolateral; 5, paratype female, habitus; 6, spermathecae, ventral view; 7, female femur and tibia IV. Scales, figs 1, 5, 7: $1 \mathrm{~cm}$; figs 2-4, 6: $1 \mathrm{~mm}$. 
Carapace length, 20.94, width, 18.42. Anterior eye row slightly procurved, posterior recurved. Eyes sizes and interdistances: AME 0.36, ALE 0.34, PME 0.24, PLE 0.29, AME-AME 0.69, AME-ALE 0.25, PME-PME 1.42, PME-PLE 0.12, ALE-PLE 0.40, OQ length, 1.79, width, 2.5, clypeus, 0.57. Fovea short, deep, recurved, width, 1.87. Labium length, 3.58, width, 3.27, with 138 cuspules. Maxillae with 139 cuspules in a group on the proximal prolateral angle. Sternum length 9.38, width 7.65 , with many long setae. Chelicerae with 12 teeth on basal promargin, 14 basal retrolateral teeth smaller. Spination: femora I-IV and palp 0. Patellae I-IV and palp 0. Tibia I, 1-1p; II, 1v, 1-1d; III, 1-1p, 1-1r; IV, 1-1v, 1p, 1r; palp, 2-2-2-1p, 2r. Metatarsi I, 1v, 1p; II, 2-1-1v, 1-1p; III, 1-1-1-1v, 1-1-1p, 1-1r; IV, 1-1v, 1-1-1-1-2p, 1-1r. Tarsi I-IV and palp 0. Scopulae: entire and dense on tarsi I-IV. Metatarsi I and II fully scopulate, III, 1/2 scopulated, IV 1/3. Length of legs and palpal segments are given in Table I. Tibia and femur IV thickened. Tibial apophysis with two branches originating from a common base, retrolateral not constricted in the middle bearing a short strong black thorn and the prolateral hardly curved at tip (Fig. 2). Male palpal bulb pyriform, embolus long. Prolateral keels present, the PS forming the embolus edge distally and not pronounced; SA represented by a denticulate row extending by almost the entire embolus length; R present, pronounced (Figs 3, 4). Types I and III urticating hairs present. Sternum, coxae and legs ventrally covered by many long hairs. Carapace black bordered by short pinkish hairs, legs black with pinkish hairs dorsally on coxae and trochanters. Abdomen black covered by long reddish hairs. Leg rings very distinct on the apex of femora and patellae. Longitudinal stripes on the femora slightly distinct and very distinct on patellae, tibiae and metatarsi (Fig. 1).

Female (Paratype, MLP 19032) (Fig. 5). Total length, not including chelicerae and spinnerets, 64.40. Carapace length, 25.09, width, 22.01. Anterior eye row slightly procurved, posterior recurved. Eyes sizes and interdistances: AME 0.32, ALE 0.45, PME 0.23, PLE 0.36, AME-AME 0.70, AME-ALE 0.32, PME-PME 1.41, PME-PLE 0.12, ALE-PLE 0.53, OQ length, 1.72, width, 2.50, clypeus, 0.65 . Fovea short, deep, recurved, width, 4.67. Labium length, 3.94, width, 3.63, with 121 cuspules. Maxillae with 157 cuspules in a group on the proximal prolateral angle. Sternum length 11.64, width 10.16, with many long setae. Chelicerae with 10 teeth on basal promargin, 18 basal retrolateral teeth smaller. Spination: femora I-IV and palp 0. Patellae I-IV and palp 0 . Tibia I, 2v, 1p; II, 1p, 1-1r; III, 2v, 1p; IV, 1-1v, 1p, 1r; palp, 2v, 1-1p, 1-1r. Metatarsi I, 2v; II, 1-1v, 1p, 1r; III, 1-1-2v, 1p; IV, 2-1-2-2v, 1p, 1-1r. Tarsi I-IV and palp 0 . Scopulae: entire and dense on tarsi I-IV. Metatarsi I and II fully scopulate, III, 3/4 scopulated, IV 1/3. Length of legs and palpal segments are given in Table II. Tibia and femur IV thickened (Fig. 7). Spermathecae short separated by a weakly sclerotized area (Fig. 6). Types I and III urticating hairs present. Sternum, coxae and legs ventrally covered by many long hairs. Carapace black bordered by short pinkish hairs, legs black with pinkish hairs dorsally on coxae and trochanters. Abdomen black covered by long reddish hairs. Leg rings very distinct on the apex of femora and patellae. Longitudinal stripes on the femora slightly distinct and very distinct on patellae, tibiae and metatarsi (Fig. 5).

Additional material examined. ARGENTINA, Chaco: Tres Naciones (near Tres Isletas, 20²0'45"S, 60²4'90”W), 2 ㅇ, X.2006, J. Barneche col. (MLP 19033). Tres Estacas (2704'18'S, 61³1'33”'W), ô (MLP 19034), 2 ( (MLP 19035), 3 juveniles (MLP 19036), I.2012, J. Barneche col.

Distribution. Known from central and western Chaco province, near Santiago del Estero province, Argentina.

Natural history. Spiders were observed in the field exhibiting a noticeable aggregation, with many specimens in a few square meters. At night, they usually stay outside the burrow waiting for a prey and can be easily found. Eupalaestrus larae sp. nov. inhabit the eco-region of transitional Chaco, between humid and dry Chaco. Specimens were found in unflooded flat grasslands open areas inside forest habitat (Fig. 8). Moreover, this species is abundant in modified and disturbed habitats such as golf fields (Jorge Barneche, pers. obs.). Burrows (Fig. 9) are deep and can easily exceed the 50 centimeters; the entrances can vary from $32.92 \mathrm{~mm}$ to $36.81 \mathrm{~mm}$ according to the spider size and sex and temperatures inside burrows can range from 30 to $33^{\circ} \mathrm{C}$ while the outside temperature in their typical habitat can reach values of 37 to $39^{\circ} \mathrm{C}$ in summer. Eupalaestrus larae sp. nov. is a sympatric species with the theraphosid Acanthoscurria chacoana Brèthes 1909, and both species can be found in the same habitat, but A. chacoana inhabit inside the forest and construct their

Tab. I. Eupalaestrus larae sp. nov., length of leg and palpal segments of male.

\begin{tabular}{lccccc}
\hline & I & II & III & IV & Palp \\
\hline Femur & 18.8 & 15.5 & 14.9 & 18.3 & 11.0 \\
Patella & 9.2 & 8.4 & 8.0 & 8.6 & 8.6 \\
Tibia & 13.5 & 12.3 & 11.7 & 15.8 & 8.7 \\
Metatarsus & 12.9 & 13.0 & 14.7 & 22.6 & - \\
Tarsus & 9.4 & 9.7 & 9.1 & 10.7 & 4.5 \\
Total & 61.9 & 59.1 & 58.5 & 76.1 & 32.9 \\
\hline
\end{tabular}

Tab. II. Eupalaestrus larae sp. nov., length of leg and palpal segments of female.

\begin{tabular}{lccccc}
\hline & I & II & III & IV & Palp \\
\hline Femur & 16.1 & 14.2 & 13.1 & 16.4 & 12.4 \\
Patella & 9.3 & 9.1 & 7.9 & 10.3 & 7.6 \\
Tibia & 11.8 & 9.9 & 9.4 & 12.9 & 8.5 \\
Metatarsus & 10.9 & 10.3 & 11.4 & 17.6 & - \\
Tarsus & 8.2 & 7.9 & 7.7 & 8.8 & 9.3 \\
Total & 56.5 & 51.5 & 49.7 & 66.3 & 38.0 \\
\hline
\end{tabular}



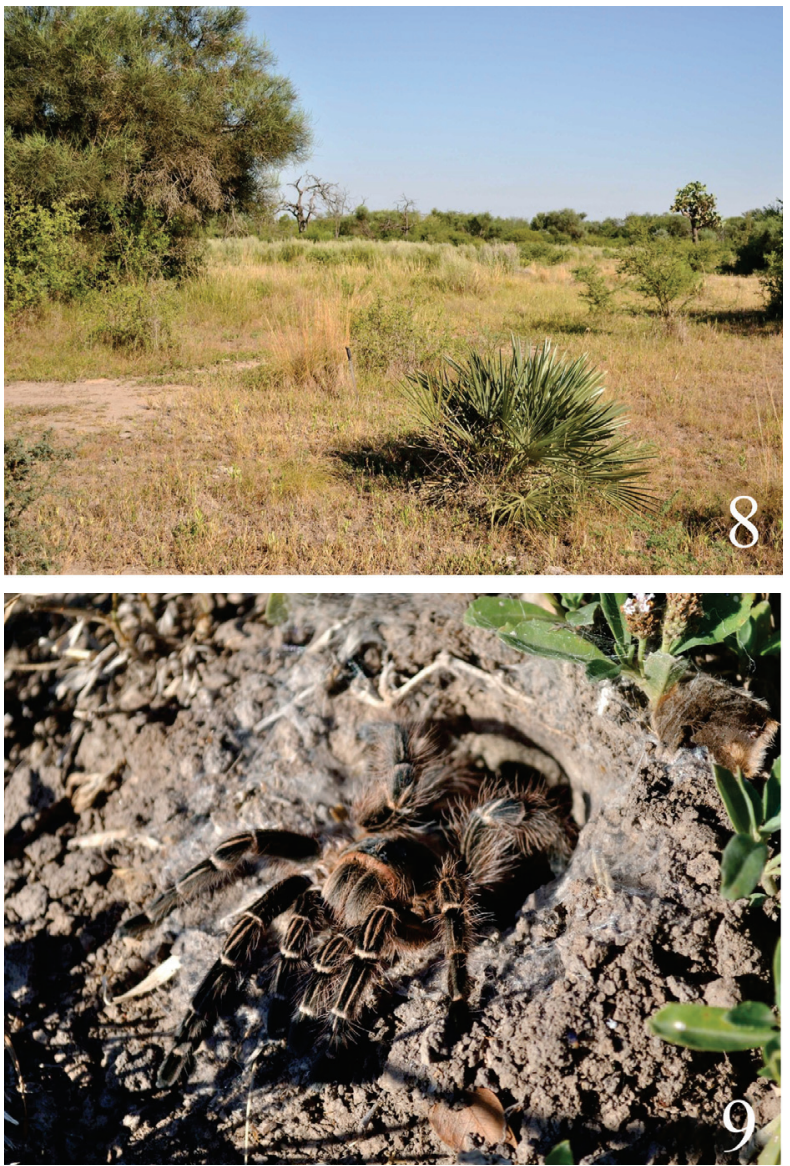

Figs 8, 9. Eupalaestrus larae sp. nov. in Chaco region: 8, habitat; 9, female at burrow entrance in the type locality.

burrows under logs or in base of trunks. An analogous situation occurs in Uruguay and Brazil, where two sympatric theraphosid species of the genus Eupalaestrus and Acanthoscurria occupy the same habitat in grasslands (PÉREz-Miles et al., 2005) and in Pantanal Matogrossensse (Rogerio Bertani, pers. comm.).

Acknowledgements. Thanks to Fernando Pérez-Miles (Facultad de Ciencias, Montevideo, Uruguay) and Rogerio Bertani
(Instituto Butantan, São Paulo, Brazil) for the critical reading of the manuscript. Authors thanks to the Comision Nacional de Investigaciones Científicas y Técnicas (CONICET); Nelson Ferretti is supported by a doctoral fellowship. Thanks to Alda González (CEPAVE, CCT, La Plata, Argentina) for their constant support and Patricio Cavallo for their valuable suggestions and comments.

\section{REFERENCES}

Bertani, R. 2000. Male palpal bulbs and homologous features in Theraphosinae (Araneae, Theraphosidae). Journal of Arachnology 28:29-42.

2001. Revision, cladistic analysis, and zoogeography of Vitalius, Nhandu, and Proshapalopus; with notes on other Theraphosinae genera (Araneae, Theraphosidae). Arquivos de Zoologia 36(3):265-356

BüChERL, W. 1947. Duas novas espécies do gênero Eupalaestrus Pocock 1901. Memórias do Instituto Butantan 20:297-314.

Coddington, J. A. \& Levi, H. W. 1991. Systematics and evolution of spiders (Araneae). Annual Review of Ecology and Systematics 22:565-592.

CoOKe, J. A. L.; Roth, V. D. \& Miller, F. H. 1972. The urticating hairs if theraphosids spiders. American Museum Novitates 2498:1-43.

Gabriel, R. 2009. Notes on the taxonomic placement of Eurypelma guyanum Simon, 1892 and Eurypelma panamense Simon, 1891 (Araneae: Theraphosidae). Journal of the British Tarantula Society 24:87-90.

Mello-Leitão, C. F. 1941. Las arañas de Córdoba, La Rioja, Catamarca, Tucumán, Salta y Jujuy colectadas por los Profesores Birabén. Revista del Museo de La Plata, Nueva Serie, Zoología 2:99-198.

Pérez-Miles, F. 1992. Revisión del género Eupalaestrus Pocock, 1901 (Araneae, Theraphosidae). Revista Brasileira de Biologia 52:2735.

Pérez-Miles, F.; Costa, F. G.; Toscano-Gadea, G. \& Mignone, A. 2005. Ecology and behaviour of the 'road tarantulas' Eupalaestrus weijenberghi and Acanthoscurria suina (Araneae, Theraphosidae) from Uruguay. Journal of Natural History 39(6):483-498.

Petrunkevitch, A. 1925. Arachnida from Panama. Transactions of the Connecticut Academy of Arts and Science 27:51-248.

Platnick, N. I. 2012. The world spider catalog, version 12.5. American Museum of Natural History. Available at: <http:// research.amnh.org/iz/spiders/catalog/INTRO1.html>. Accessed on: 20.04.2012.

Raven, R. J. 1990. Comments on the proposed precedence of Aphonopelma Pocock, 1901 (Arachnida, Araneae) over Rechostica Simon, 1892. Bulletin of Zoological Nomenclature 47(2): 126.

Schiapelli, R. D. \& Gerschman de Pikelin, B. S. 1979. Las arañas de la subfamilia Theraphosinae (Araneae, Theraphosidae). Revista del Museo Argentino de Ciencias Naturales 5:287-330. 